\title{
Key success factors of human resources management of the Office of Justice Fund as a result of a study on evaluating enforcement of the Justice Fund Act B.E. 2558 (2015)
}

\author{
Yutthapong Leelakitpaisarn ${ }^{1}$, Pornpen Traiphong², Tananyaphat Srinathiyawasin ${ }^{3}$, Thanachart \\ Paliyawate $^{4}$ \\ ${ }^{1}$ School of Law and Politics, Suan Dusit University, \\ ${ }^{2}$ Faculty of Social Sciences, Srinakharinwirot University, \\ ${ }^{3}$ Faculty of Humanities and Social Sciences, Suan Dusit University \\ ${ }^{4}$ Faculty of Law, Ramkhamhaeng University \\ ${ }^{1}$ Y16767@ @otmail.com, ${ }^{2}$ pornpent@g.swu.ac.th, ${ }^{3}$ tananyaphat@yahoo.com , ${ }^{4}$ thanachartp@ ru.ac.th
}

\begin{abstract}
This research aims to apply result of evaluating enforcement of the Justice Fund Act B.E. 2558 (2015) in the 2nd element, law enforcement into an analysis of key success factors of the Office of Justice Fund (JFO) 's human resource management for finding way of enhancing efficiency of the law enforcement by revision of the law in line with necessity of making a law and social context and for increasing efficiency of the office management which is a part of the Justice Fund's operation. Means of multi-stage sampling and purposive sampling were exercised to select 238 informants. The qualitative research including documentary research, in-depth interview, focus group discussion, and seminar to brainstorm and criticize a preliminary research result were carried out to collect the data. The research eventually resulted the following key success factors of the Office of Justice Fund's human resources management: (1) Selecting competent law enforcement personnel pursuant to nature of work; (2) Determining manpower fitting to quantity of work; (3) Assessing performance efficiently; (4) Developing personnel incessantly; (5) Generating morale and mental support to those personnel and (6) Creating surroundings fitting to work.
\end{abstract}

Keywords

Key success factors, human resources management, justice fund

Article Received: 10 August 2020, Revised: 25 October 2020, Accepted: 18 November 2020

\section{Introduction}

Thailand's legislation has provided a number of laws in particular over one thousand Acts as of the year 2017. Many of them are outdated owing to being proclaimed long time ago, non-revision in line with current circumstances and non-pursuance of international obligations. Thus, public sector has endeavored to revise those laws in order to catch up with current social context and enhance potential of Thailand's competition. Section 77 of the Constitution of Kingdom of Thailand B.E. 2560 (2017) requires making a law only to the extent of necessity, repeal or revise laws that are no longer necessary or unsuitable to the circumstances. During the time Ministry of Justice has implemented a policy of diminishing difference in justice process for people's equal access into justice by development of several laws facilitating justice. Thus, the Office of Justice Affairs (OJA) provided a study on evaluating enforcement of the Justice Fund Act B.E. 2558 (2015) which was developed to enable people to access justice equally and equivalently. The Act stipulates the Justice Fund to be a source of fund for helping people in respect of litigation, temporary release of accused or defendant, human rights violated and dissemination of legal knowledge to the people.

The study used a law enforcement evaluation tool developed by the Office of Justice Affairs and [1]. With important assessment elements. (1) The necessity of having / applying current laws. (2) Provisions of the Law. (3) Law enforcement; (4) Knowledge, attitude and behavior of law enforcement. (5) Consequences from law enforcement. (6)
Impact from law enforcement. (7) The cost of enacting and applying the law as compared to the stake that the public or stakeholders will receive. This project select to evaluate these following elements: (1) Provisions of law; (2) Law enforcement; (3) Knowledge, attitudes and behaviors of the enforced and (4) Consequences from law enforcement to analyze its achievement of the law pursuant to the Constitution of the Kingdom of Thailand whether its enforcement conforms to its intent or benefits Thai people and society or not so as to find conclusion and suggestion to repeal, improve or revise provisions of law for more suitability as well as ability to assist people for more efficient access into justice process. In evaluating the law enforcement, one key success factors of the Office of Justice Fund (JFO)'s human resource management is office management of the Justice Fund. For development of such key success, additional in-depth analysis to the $2^{\text {nd }}$ element, law enforcement was done for finding a way forward to increase the justice fund's efficiency by the JFO's management.

\section{Research Objectives}

The objectives of this research article were to apply result of evaluating enforcement of the Justice Fund Act B.E. 2558 (2015) in the $2^{\text {nd }}$ element, law enforcement into analysis of key success factor of the Office of Justice Fund (JFO)'s human resource management 


\section{Research Methods}

\section{A. Research Design}

In respect of population in this research, data collection in the field was determined by selecting provinces where have received the request for the Justice fund's assistance in the first two sequences in each region according to the JFO's information in the budgetary year i.e. Central region included Bangkok Metropolis and Chainart province, Northern region included Kamphaeng Phet province and Nakorn Sawan province, Northeastern region included Nakorn Ratchasima province and Buriram province and Southern region included Krabi province and Surat Thani province.

Sample groups or informants in this research comprise with:

\begin{tabular}{|c|c|c|c|}
\hline Sample groups & $\begin{array}{l}\text { Number } \\
\text { of } \\
\text { provinces }\end{array}$ & $\begin{array}{l}\text { Number } \\
\text { of sample } \\
\text { group in } \\
\text { each } \\
\text { province }\end{array}$ & $\begin{array}{l}\text { Total } \\
\text { number } \\
\text { (people) }\end{array}$ \\
\hline $\begin{array}{l}\text { Executives or } \\
\text { related authorities } \\
\text { in policy level }\end{array}$ & $\begin{array}{l}1 \text { province } \\
\text { (Bangkok) }\end{array}$ & 8 & 8 \\
\hline $\begin{array}{l}\text { Personnel } \\
\text { involved in the } \\
\text { Justice Fund Act } \\
\text { B.E. } 2558(2015)\end{array}$ & $\begin{array}{l}8 \\
\text { provinces }\end{array}$ & 8 & 64 \\
\hline $\begin{array}{l}\text { Personnel } \\
\text { involved in the } \\
\text { Justice Fund Act } \\
\text { B.E. } 2558(2015) \\
\text { only the } 3^{\text {rd }} \text { and } \\
4^{\text {th }} \text { missions } \\
\text { (helping the } \\
\text { human rights } \\
\text { violated and } \\
\text { dissemination of } \\
\text { legal knowledge } \\
\text { to the people) }\end{array}$ & $\begin{array}{l}1 \text { province } \\
\text { (Bangkok) }\end{array}$ & 6 & 6 \\
\hline $\begin{array}{l}\text { People or target } \\
\text { groups requesting } \\
\text { for various } \\
\text { assistances by the } \\
\text { Fund pursuant to } \\
\text { the Act and the } \\
\text { Fund } \\
\text { Committee's } \\
\text { regulation on } \\
\text { criteria, means and } \\
\text { conditions of } \\
\text { assisting people in } \\
\text { litigation B.E. } \\
2559(2016)\end{array}$ & $\begin{array}{l}8 \\
\text { provinces }\end{array}$ & 20 & 160 \\
\hline Total & $\begin{array}{l}8 \\
\text { provinces }\end{array}$ & & 238 \\
\hline
\end{tabular}

Table 1 Population and sample groups in this research

\section{B. Research Process}

The research utilized a qualitative research which included:
1) In-depth Interview

An interview form containing structure of various questions provided in line with the legislation impact assessment tool was utilized to collect data. The informants are selected by multi-stage random sampling and quota sampling to determine number of informants in relevant proportion and by purposive sampling for suitability of informing data pursuant to criteria in the law enforcement evaluation tool.

2) Focus group discussion

Two sessions of focus group discussion were organized and participated by academics, qualified, officials of both central and provincial agencies involved in the Justice Fund Act and delegates of related agencies in justice process as well as receivers of the justice fund's services. Participants of each session were not exceeding 30 people. The first session was held in provincial area and another session was held in Bangkok Metropolis.

3) Seminar

A seminar was held to brainstorm and criticize a preliminary result of evaluating enforcement of the Justice Fund Act, participated by officials of both central and provincial agencies involved in the Justice Fund Act and delegates of related agencies in justice process as well as other interested people for around 100 people.

\section{Results}

The research had the following findings as shown overall below:

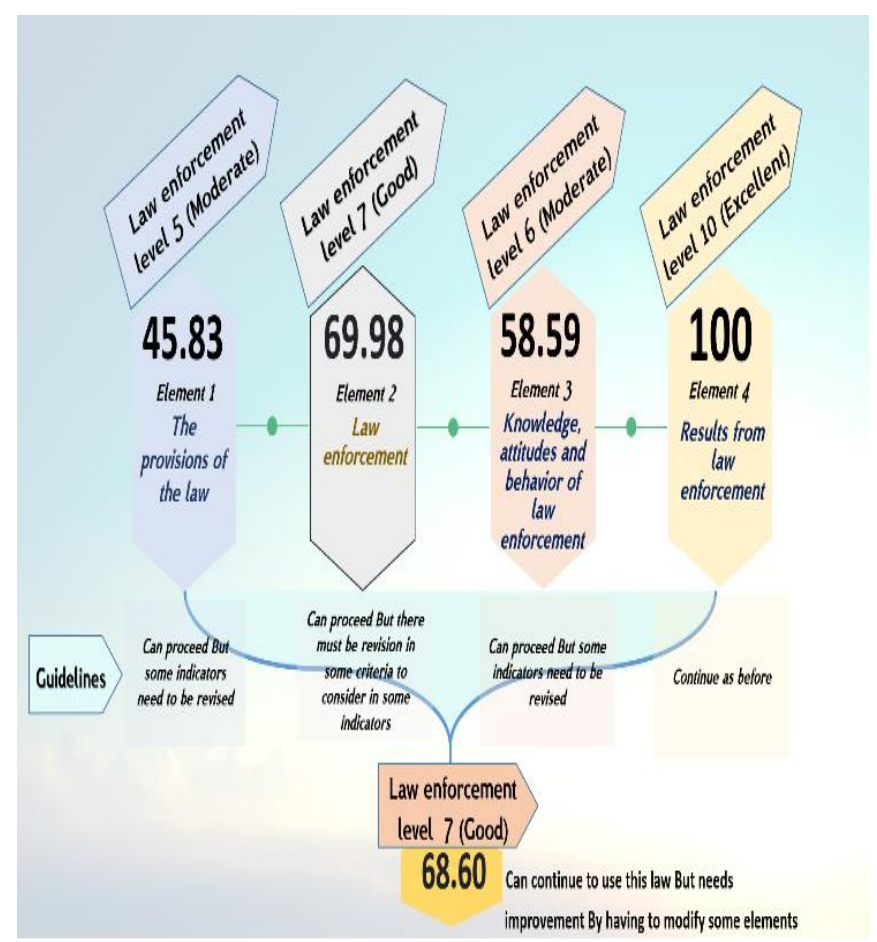

Figure 1 Overall result of evaluating enfocement of the Justice Fund Act B.E. 2558 (2015)

As for evaluating enforcement of the Justice Fund Act B.E. 2558 (2015), overall level of the law enforcement resulted a mean of 68.60 percentage rated in level of 7 (good), considered to be further applicable but some elements must be revised. After due consideration of the $2^{\text {nd }}$ element, law enforcement resulted a mean of 69.98 percentage rated in level of 7 (good), considered to be further applicable but 
some criteria in certain indicators must be revised. Upon taking into consideration of indicators, significant findings are shown in the table below:

\begin{tabular}{|c|c|c|c|c|}
\hline Elements & $\begin{array}{l}\text { Indicator } \\
\mathrm{S}\end{array}$ & $\begin{array}{l}\text { Level } \\
\text { of law } \\
\text { enforce } \\
\text { ment }\end{array}$ & $\begin{array}{l}\text { Guidelin } \\
\text { e for } \\
\text { operation }\end{array}$ & $\begin{array}{l}\text { Guideli } \\
\text { ne for } \\
\text { further } \\
\text { develop } \\
\text { ment }\end{array}$ \\
\hline \multirow{3}{*}{$\begin{array}{l}\text { The } 2^{\text {nd }} \\
\text { element, } \\
\text { law } \\
\text { enforceme } \\
\text { nt, } 69.98 \\
\text { rated in } \\
\text { level of } 7 \\
\text { (good), } \\
\text { considered } \\
\text { to be } \\
\text { further } \\
\text { applicable } \\
\text { but some } \\
\text { criteria in } \\
\text { certain } \\
\text { indicators } \\
\text { must be } \\
\text { revised }\end{array}$} & $\begin{array}{l}\text { Indicator } \\
2.1 \text { : } \\
\text { Selection } \\
\text { of the } \\
\text { law } \\
\text { enforce } \\
\text { ment } \\
\text { personne } \\
1\end{array}$ & $\begin{array}{l}82.47 \\
\text { rated in } \\
\text { level of } \\
9 \\
\text { (excelle } \\
\text { nt) }\end{array}$ & $\begin{array}{l}\text { To be } \\
\text { further } \\
\text { applicabl } \\
\text { e with } \\
\text { overall } \\
\text { review }\end{array}$ & - \\
\hline & $\begin{array}{l}\text { Indicator } \\
2.2 \text { : } \\
\text { Supervisi } \\
\text { on and } \\
\text { monitori } \\
\text { ng of the } \\
\text { law } \\
\text { enforce } \\
\text { ment } \\
\text { personne } \\
1\end{array}$ & $\begin{array}{l}68.46 \\
\text { rated in } \\
\text { level of } \\
7 \\
\text { (good) }\end{array}$ & $\begin{array}{l}\text { To be } \\
\text { further } \\
\text { applicabl } \\
\text { e but } \\
\text { some } \\
\text { criteria } \\
\text { must be } \\
\text { revised }\end{array}$ & $\begin{array}{l}\text { Should } \\
\text { revise/ } \\
\text { improve } \\
\text { the } 7^{\text {th }} \\
\text { criteria }\end{array}$ \\
\hline & $\begin{array}{l}\text { Indicator } \\
2.3: \\
\text { Human } \\
\text { resource } \\
\text { and } \\
\text { material } \\
\text { resource } \\
\text { administr } \\
\text { ation }\end{array}$ & $\begin{array}{l}59.00 \\
\text { rated in } \\
\text { level of } \\
6 \\
\text { (moder } \\
\text { ate) }\end{array}$ & $\begin{array}{l}\text { To be } \\
\text { further } \\
\text { applicabl } \\
\text { e but } \\
\text { almost } \\
\text { all } \\
\text { criteria } \\
\text { must be } \\
\text { revised }\end{array}$ & $\begin{array}{l}\text { Should } \\
\text { revise/ } \\
\text { improve } \\
\text { the } 2^{\text {nd }} \text {, } \\
4^{\text {th }} \text { and } \\
5^{\text {th }} \\
\text { criteria }\end{array}$ \\
\hline
\end{tabular}

Table 2 Overall result of evaluating enforcement of the Justice Fund Act B.E. 2558 (2015), breakdown by elements and indicators

After due consideration of the $2^{\text {nd }}$ element namely law enforcement, its result was a mean of 69.98 percentage rated in level of 7 (good), and considered to be further applicable; however, some criteria in certain indicators must be revised. Such findings are in connection with key success factors of human resource management of the Office of Justice Fund as follows: As regards the indicator 2.1: Selection of the law enforcement personnel resulted a mean of 82.47 percentage rated in level of 9 (excellent), some suggestions for operation includes: the officials' service mind should be emphasized for further development and the personnel should be secured by putting them into posts of state officer or official and by appropriate remuneration. As regards the indicator 2.2: Supervision and monitoring of the law enforcement personnel resulted a mean of 68.46 percentage rated in level of 7 (good), some suggestions for operation includes: Result from the assessment of the officials' service quality or performance should be applied to improve or develop efficiency of service quality and the
Office of Permanent Secretary should provide a central assessment form or set up a system for identical operation in every province. As regards the indicator 2.3: Human resource and material resource administration resulted a mean of 59.00 percentage rated in level of 6 (moderate), some suggestions for operation includes: new process which diminishes steps of service action should be provided and protection measures for lessening risks of the officials' operations should be taken as well as any equipment utilized in operations should be supported as a form of morale and mental support together with creating surroundings fitting to work and the officials' operations.

Although result of the $2^{\text {nd }}$ element namely law enforcement was rated in level of 7 (good), several additional actions have still been necessary for higher result of operations. Significant issues which are key success factors of the Office of Justice Fund (JFO)'s human resource management can be summarized as follows:

1) Selecting competent law enforcement personnel pursuant to nature of work;

2) Determining manpower fitting to quantity of work;

3) Assessing performance efficiently;

4) Developing personnel incessantly;

5) Generating morale and mental support to those personnel and

6) Creating surroundings fitting to work

The aforementioned significant issues which are key success factors are in accordance with a result of two sessions of focus group discussion in the following issues:

1) Should develop and generate morale and mental support and facilities support to those operative personnel;

2) Should pay attention to personnel development by organizing regularly training course being essential to operations e.g. inquiry technique, budget and personnel management;

3) Should pay attention to the personnel' retention rate due to rather high rate of job rotation and

4) Should keep in mind of personnel's safety when conducting on duties in various risky areas

Furthermore, as for the seminar organized for brainstorming and criticizing a preliminary result of evaluating enforcement of the Justice Fund Act, participants expressed their opinions and suggestions about such result in conformity with key success factors of the Office of Justice Fund (JFO)'s human resource management as follows:

1) Manpower fitting to quantity of work;

2) Human resource management system and various facilities e.g. information technology, vehicles to be used in going to the field work, communication devices;

3) Incessant development of personnel's knowledge and capacity and

4) Efficient system for monitoring and assessment of operations 


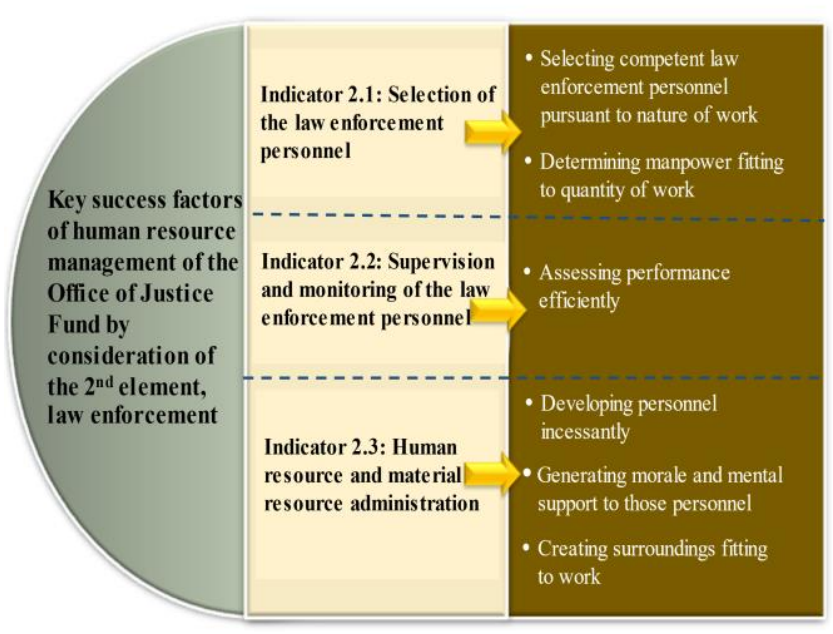

Figure 2 Key success factors of the Office of Justice Fund (JFO)'s human resource management

\section{Discussions}

1. As for the result of evaluating enforcement of the Justice Fund Act B.E. 2558 (2015) through the law enforcement evaluation tool developed by the Office of Justice Affairs (OJA), overall level of the law enforcement resulted a mean of 68.60 percentage rated in level of 7 (good), considered to be further applicable but some elements must be revised. In particular, by consideration of the 2nd element, law enforcement as contained in the law enforcement evaluation tool it resulted a mean of 69.98 percentage rated in level of 7 (good), considered to be further applicable but some criteria in certain indicators must be revised. This research points out several additional actions which are necessary for moving forward and attaining higher result of operations. Thus, result from the assessment of the officials' service quality or performance should be truly applied to improve or develop efficiency of service quality. In respect of human resource management and material resource management, proportion of officials 'manpower, building of security, morale and mental support are highlighted. Hence, key success factors of the JFO's human resource management depend on incessant personnel development, generating morale and mental support to those personnel and creating surroundings fitting to work. These findings are in conformity with a research work of [2] in the subject of the ways for improving management of the Justice Fund of Thailand that aimed to study process of legal assistance and financial assistance in justice process and to seek for ways of appropriate management for growth and sustainability of the Justice Fund of Thailand. Such research resulted that the JFO should formulate expicit and standardized operational regulations on efficient development of human resource management and generate morale and mental support in performing works as well as create trustworthiness to people by promoting building strong participatory network. In addition, [3] researched in a project of the Justice Fund accomplishment evaluation from its commencement in the year 2006 to almost decade anniversary. It resulted many suggestions i.e. should conduct a survey of legal problems encoutered in particular by poor people for knowing of direction, trend and nature of those legal problems before categorizing them, (the JFO) should review preceding strategies and plans, set priority of actions and take actual actions, should revise to provide new manual containing diagrams that visualize procedure, steps, direction, details of operations, remark, caution or other details to enable personnel to learn and utilize quickly and concretely in their actions, should organize meetings and invite the law enforcement personnel to participate in expressing opinions for any formulation of regulation, guidelines and other guidance in order to evade problems in practice and (the Rights and Liberties Protection Deparment) should establish an agency or a center for counseling in central part for any queries of officers in various areas in benefit of efficient operation and process.

2. As regard the result of evaluating enforcement of the Justice Fund Act B.E. 2558 (2015) in relation to key success factors of the JFO's human resource management found from in-depth interview and focus group discussion i.e. selecting competent law enforcement personnel pursuant to nature of work, determining manpower fitting to quantity of work and assessing performance efficiently, these findings are in conformity with a research work of Siyaporn Pongwatanakorn (2015) in the subject of problems of the provincial office of justice fund in the justice fund management after its decentralization to provincial level. The research resulted that a decentralization of the justice fund to provincial level which was a central policy has not yet been implemented well as it should be by local and provincial agencies for instance comprehending objectives of the Justice Fund Act B.E. 2558 (2015) and the provincial justice fund sub-committee's extent of discretion in taking into consideration of financial assistance provided by the justice fund. As for structure of the provincial justice fund sub-committee, most panelists being delegates of state agencies in justice process and having expertise and experiences of judicial proceedings exercised their discretion that might be beyond scope and addressed to making decision by their own. Such regard did not comply with the justice fund's objective which provided chance of access into justice. Moreover, a problem of making case statement was arisen by insufficient number of personnel and circulation of personnel in office by the Provincial Justice Office's complex management, as making case statement was an important step of assembling consideration and decision of the provincial justice fund sub-committee.

\section{Recommendations}

From this research result of key success factors of the Office of Justice Fund (JFO)'s human resource management that taking account of the result of evaluating enforcement of the Justice Fund Act B.E. 2558 (2015) through the law enforcement evaluation tool, the authors have the following suggestions.

1) Should apply result of operation and conclusion of the justice fund's implementation into review and revision of any regulation relating to the justice fund in particular the human resource management-related;

2) Should apply result from the assessment of the officials' service quality or performance to improve or develop 
seriously efficiency of service quality; furthermore, the Office of Permanent Secretary should provide a central assessment form or set up a system for identical operation in every province;

3) Should revise or improve proportion of the law enforcement personnel being sufficient to number of service receivers in order to prepare for tendency of higher quantity of works in the future and should create new process which diminishes steps of service or apply other means to help increase efficiency of the justice fund personnel's performance;

4) Should create morale and mental support and eulogize any personnel having prominent performance pursuant to the designated criteria by putting qualified personnel into posts of state officer or official and should increase amount of salary on yearly basis and escalate amount of per diem allowance in case of working out of normal place of work;

5) Should add protection measures for lessening risks of the officials' operations and support equipment utilized in their operations;

6) Should support performing duties and works by creating surroundings fitting to work by arranging proportional place of works fitting to working and nature of work and planning of spending budget on improving place of works to be more relevance and

7) Should raise realization on monitoring and evaluation or survey of the service receivers' changing behavior after receiving assistance from the justice fund by setting up a system of monitoring and evaluation or survey of the service receivers' changing behavior

\section{Recommendations for further research}

This research result includes some recommendations for further research as set forth below:

1) As for a finding that the justice fund encounters problems of operation arising out of various rules and regulations, such issue should be researched for review and revision of related rules and regulation in pursuance to its findings and

2) Should study about finding a way or creating curriculum of personnel development in particular performing duties in the Office of Justice Fund

\section{CONCLUSION}

Various key success factors of the Office of Justice Fund (JFO)'s human resource management which is a part of the office management and likewise the Justice Fund's operation can be taken into actual actions based on effective enforcement of the Justice Fund Act B.E. 2558 (2015) and by coping with existing problems and limitations. Most of all, such key success factors have still been necessary to emphasize on human resource development in every level and multi-disciplinary personnel under the national strategy and the Ministry's mission and plan of actions as well as to conform with current changing social context and prospective circumstances in Thailand.

\section{Acknowledgment}

This research was supported by Office of Justice Affair for the fiscal year 2018

\section{References}

[1] U. Jaktrimongkol, Project of Monitoring and Evaluating Enforcement of Laws in Justice Process: Research for Developing the Law Enforcement Evaluation Tool. Bangkok: Educational and Psychological Test Bureau, Srinakharinwirot University, 2017.

[2] V. Yamyim, Guidelines for the development of fair fund management for Thailand. Bangkok: Journal of Criminology and Forensic Science. Police Cadet Academy, Year 3, Issue 1, January June 2017, 2017.

[3] T. Bowornnantakul, Justice fund accomplishment evaluation project. Research report. Nonthaburi: Rights and Liberties Protection Department, Ministry of Justice, 2015.

[4] S. Pongwatanakorn, Problems of the provincial office of justice fund in the justice fund management after its decentralization to provincial level. Pathumthani: Thammasat University, 2015. 